from year to year. The threshold of activity of the insect may be so low as $7-10^{\circ} \mathrm{C}$., while a temperature of $13-14^{\circ} \mathrm{C}$. is most favourable to a long life of the insect in the absence of food : both above and below this temperature life is definitely shorter at comparable humidities. For long life a high humidity is essential. At $45^{\circ} \mathrm{C}$. (113 $3^{\circ}$.) the eggs succumb in one hour, and the adults in the same time at a temperature one degree lower.

As regards insecticidal methods of eradication, sulphur dioxide has proved to be a poor ovicide and not very toxic to the immature bed-bugs. An account is given of the circumstances leading to the abandonment of orthodichlorbenzene as a fumigant against the insect. Heavy naphtha is shown to be a useful contact insecticide, while its vapour action is particularly effective. The practical uses of hydrogen cyanide and heavy naphtha as fumigants have been investigated and conditions governing their application specified. Details are also given of the experimental methods used to test the effects of the insecticides employed on man. Of those investigated, orthodichlorbenzene is shown to be dangerous and heavy naphtha relatively safe. The concluding section is concerned with building design in relation to bedbug infestation. It is stressed that new buildings should be so constructed as to provide the minimum harbourage for the insect and allow of its cheap and easy eradication in the event of infestation occurring.

\section{Determining Colour in Telephone Cable}

A methon is described by C. T. Wyman (Bell Lab. Rec., 20, No. 11, July 1942) of correctly determining the colour of conductor insulation papers, which, moreover, permits the use of a range of colours otherwise unobtainable. The system uses a scheme of colour notation developed in recent years by $\mathbf{A}$. $\mathrm{H}$. Munsell, in which each colour is specified by stating certain values for three parameters called 'hue', 'value' and 'chroma'.

'Hue' corresponds most nearly to what is normally called colour, five basic hues being used-red, yellow, green, blue and purple. Five intermediate coloursyellow-red, green-yellow, blue-green, purple-blue and red-purple-are also designated, and each of these ten hues is divided decimally to give ten sub-hues. Any hue is specified by a letter and a number from one to ten; thus $2 R$ represents a red approaching the red-purple. 'Value' represents that characteristic most nearly described as 'lightness' or 'darkness', and is specified by a number from one to ten following the letter or letters designating 'hue'. 'Chroma' represents the degree of colour of any one hue, and is also represented by a number immediately following the 'value' number, but separated from it by an oblique line. A zero chroma would be a complete absence of colour, and would thus be a light or dark grey, depending on the value. A simple system of matching is thus available. It is not necessary to make samples of all the colours, however, because any colour may be obtained by mixing certain other colours.

In the method described several differently coloured disks are interleaved and the assembly is caused to rotate. The individual colours disappear and are replaced by a single colour corresponding to the particular combination. The Munsell Color Co. makes up a series of disks using light-fast dyes. These disks have a central hole to fit on the spindle of a motor, and a radial slit from rim to centre. A group of colour disks is selected which, when properly proportioned, will give the required colour, the disks being interleaved through the medium of the radial slots. The method has recently been adopted to secure colour standards for cable insulation, using a card carrying a peripheral scale mounted on the spindle behind the disks to provide a ready means of determining the percentage of each colour that is exposed.

\section{Thickness of Aluminium Oxide Coatings}

ALuminium surfaces in telephone apparatus are sometimes protected by an electrochemically deposited oxide coating. It is important to control the thickness of these deposits and several methods have been tried. A majority of them, such as scratching the surface, stripping the deposit to weigh it, and measuring the thickness of a cross-sectional cut under the microscope involve destruction of the sample. A quick and reliable method, which is not subject to this limitation, is described in the Bell Laboratory Record of July 1942. It measures the voltage required to break down the oxide coating and punctures the specimen with so small a hole that it is not appreciably marred. A chromium-plated sphere about $\frac{1}{8}$ in. diameter is pressed against a thin plate of oxidecoated aluminium until the force, as indicated by a calibrated spring, is $1-2 \mathrm{kgm}$. Increasing voltages up to 1,500 are then applied, and that at which breakdown occurs is noted, the current being limited by resistors. This method has been used in the Bell Laboratories to study the relation between film thickness and the time to make the deposits electrochemically. The thickness obtained by an average of several readings is generally within ten per cent of the value found by direct measurement with a microscope.

\section{Alcoholism and Crime}

IN a recent paper (Quart. J. Studies on Alcohol, 2, 686 ; 1942) Dr. Ralph S. Banay, chief psychiatrist to Sing Sing Prison, New York, records his experience of this subject based on detailed examinations, laboratory studies, social investigations and years of follow-up in confinement or supervision on parole. Statistical data showed that the principal difference between the alcoholic criminal and the non-alcoholic criminal was the high incidence of assault among the former, while in the latter crimes against property took precedence. This seemed to suggest that the primarily intemperate individual was drawn into crime not only for the need of money but also by the increased irritability, irascibility and pugnacity of the protracted alcoholic state. In conclusion, Dr. Banay deplores the fact that though a large number of all types of alcoholic offenders are passing through many corrective institutions throughout the United States, little is done for the study, understanding, prevention and treatment of them.

\section{Dr. Wilhelm Camerer}

Dr. Johannes Friedrich Wilherm Camerer, an eminent physiologist and pædiatrician, was born at Stuttgart, the son of a well-known medical man, on October 17, 1842. After studying medicine at Tübingen and Vienna, he qualified in 1866 and for some years was engaged in private practice and public health work. Ill-health, however, compelled him to 
abandon these activities, and he devoted himself to scientific research at Urach in Würtemberg. His principal work was connected with metabolism in the child, on which he published a classic entitled "Der Stoffwechsel des Kindes von der Geburt bis zur Beendigung des Wachstums" in 1894, for which he was awarded the Niepel Prize. He also studied the metabolism in obesity, gout, diabetes mellitus and chronic renal and cardiac disease. In 1908 he contributed two important articles to Pfaundler and Schlossmann's "Diseases of Children" on "Metabolism and Nutrition in the First Year of Life" and "Children's Growth in Weight and Height.". For some years he collaborated with Fechner, the experimental psychologist, in experiments on taste and touch. His interest in public health is shown by his papers on infant mortality and diphtheria. In recognition of his labours he was elected to an honorary doctorate of the Faculty of Natural Science of the University of Tübingen. He died on March 25, 1910.

\section{ASLIB Conference, 1942}

THE Association of Special Libraries and Information Bureaux has arranged a conference to be held during November 7-8 in the rooms of the Royal Society. The preliminary programme includes an address by Sir Richard Gregory on "International Systems and Standards", a symposium on the use of microfilm, and papers on library training and on war-time books and periodicals. Most of the papers will be available in advance. It is also announced that discussion groups are to be formed in provincial centres, where those unable to attend the London conference can meet to discuss the papers presented.

\section{The Nutrition Society}

A WHOLE-DAY conference of the Nutrition Society will be held at the London School of Hygiene, Keppel Street, London, W.C.1, on October 17, to discuss "Trace Elements in Relation to Health". Papers will be read by Dr. H. H. Green ("Significance of Trace Elements in Relation to Diseases of Plants and Animals"), Dr. R. L. Mitchell ("Distribution of Trace Elements in Soils and Grasses"), Prof. D. Keilin and Dr. T. Mann ("Copper, Zine and other Trace Elements in relation to Physiological Function and Enzyme Systems"), Prof. T. Dalling ("Enzootic Ataxia or 'Swayback' of Lambs in England in relation to Copper Feeding of Ewes during Pregnancy"-film with running commentary), Sir Charles Martin ("Cobalt and other Trace Elements in relation to Disease in Australasia"), Dr. W. Lyle Stewart ("Sheep 'Pining' in Britain"), Dr. M. M. Murray ("Fluorine in Human Nutrition; $a$, Biochemical Aspects"), Dr. D. C. Wilson ("Fluorine in Human Nutrition; $b$, Clinical Appreciation of Fluorine Distribution"), Mr. F. H. Kemp ("Fluorine in Human Nutrition; $c$, Radiological Investigations"), Mr. F. Blakemore ("Industrial Fluorosis of Animals in England"), Mr. W. S. Ferguson ("Teart' of Somerset; a Molybdenosis of Farm Animals"), Dr. R. A. MeCance and Miss E. M. Widdowson ("Absorption and Excretion ot Trace Elements"). The chair will be taken at the morning session by Dr. J. Russell Greig, and at the afternoon session by Prof. C. R. Harington. Further details of the Nutrition Society can be obtained from the hon. secretary, Dr. Leslie Harris, Nutritional Laboratory, Cambridge.

\section{Announcements}

Sir Henry Dale, president of the Royal Society, has accepted the directorship of the Laboratories of the Royal Institution, with the Fullerian professorship, in succession to the late Sir William Bragg. Sir Henry has expressed the wish that his appointment should be limited to a period of three years, so that the managers of the Royal Institution may then be free to consider their future policy.

Dr. Dudley Stamp has been appointed adviser on rural land utilization to the Minister of Agriculture. Dr. Stamp is director of the Land Utilization Survey of Great Britain and was vice-chairman of the Scott Committee on the utilization of land in rural areas.

DR. JoHN F. J. DiPPY, of the staff of Cardiff Technical College, has been appointed head of the Chemistry Department of Wigan and District Mining and Technical College, in succession to Dr. T. Heap, who has been appointed principal of Batley Technical College.

At the annual general meeting of the Physical Society held on October 2 the following officers were elected for the year 1942-43: President, Sir Charles Darwin; New Vice-Presidents, Prof. C. D. Ellis and Dr. H. T. Flint; Honorary Treasurer, Dr. C. C. Paterson; Honorary Secretaries, Mr. J. H. Awbery (Papers) and Dr. W. Jevons (Business); Honorary Foreign Secretary, Sir Owen Richardson; Honorary Librarian, Prof. L. C. Martin; New Members of Council, Mr. E. R. Davies, Dr. W. B. Mann, Mr. A. J. Philpot, Prof. H. C. Webster, Dr. W. D. Wright.

LORD HIRST OF WitTon, honorary member of the Institution of Electrical Engineers, has given $£ 20,000$ for the use of the Benevolent Fund of the Institution. It will be known as the Lord Hirst Fund to give assistance to applicants for help (or to their dependants) who have rendered important services to electrical science, or electrical industry or electrical engineering.

The Institute of Physics has arranged a discussion on the "Education and Training of Physicists", to be held at the Royal Institution on October 12. The discussion, which is to be in two sessions beginning at 10.30 a.m. and 2 p.m., will be based on the memorandum on the subject prepared by the Planning Committee of the Institute.

Already the Association of Scientific Workers has organized two conferences in London and two area conferences on the theme of "Science for Victory". A third area conference is to be held for South Wales at the Royal Hotel, Cardiff, on October 18. It will be in two sessions, beginning at 10 a.m. and 2.15 p.m. Five speakers lead each session, at the end of which there will be an hour for discussion. Abstracts may be obtained from the Association prior to the meeting.

THE name of Dr. Wadie Tadros should have been included as a joint author with Dr. J. M. Robson and Prof. A. Schönberg of the letter entitled "A New Synthetic Estrogen with Prolonged Action when Given Orally", published in Nature of July 5, p. 22. The omission arose through difficulties of rapid communication with Egypt. 